\title{
PENERAPAN MODEL JIGSAW BERBANTU PERMAIANAN ULTRA 3D UNTUK PENINGKATKAN PEMAHAMAN MATEMATIS
}

\author{
Titin Safitri $^{1 \bowtie}$, Sucipto $^{2}$ dan Henry Suryo Bintoro ${ }^{3}$ \\ ${ }^{1}$ Prodi Pendidikan Guru Sekolah Dasar, Universitas Muria Kudus \\ ${ }^{2}$ Prodi Bimbingan dan Konseling, Universitas Muria Kudus \\ ${ }^{3}$ Prodi Pendidikan Matematika, Universitas Muria Kudus
}

\section{Info Artikel}

Sejarah Artikel:

Diterima 10 Agt 2018

Direvisi 4 Sept 2018

Disetujui 29 Okt 2018

Keywords: Jigsaw Model, Mathematical

Understanding, ULTRA

3D, Properties of Flat

Building

Paper type:

Research paper

\begin{abstract}
This study aims to describe the improvement of students' learning activities, describe the improvement of teacher's teaching skills in learning management, and to find out the improvement of students' mathematical understanding by using Jigsaw's learning model with three-dimensional snake ladder game on geometrical properties in grade III of SD N 3 Ngeling. The classroom action research has been conducted in grade III SD N 3 Ngeling with 28 research subjects. The result of the research shows that mathematical understanding on properties of flat building a significant percentage reached the average percentage between cycle I (71.43\%) and cycle II (82.14\%). It supported by the improvement of student learning activities and teacher's teaching skills in each cycle. Students learning activity has improved from the average score 2.31 in cycle I with sufficient criteria; it improves to 2.53 in cycle II with good criteria. The results of teacher's teaching skills also improved from the average score 3.07 with good criteria, increased to an average score 3.35 in cycle II with very good criteria
\end{abstract}

\begin{abstract}
Abstrak
Penelitian ini bertujuan untuk mendiskripsikan peningkatan aktivitas belajar siswa, mendeskripsikan peningkatan keterampilan mengajar guru dalam mengelola pembelajaran, dan menemukan peningkatan kemampuan pemahaman matematis siswa menggunakan model pembelajaran Jigsaw dengan permainan ular tangga tiga dimensi (ULTRA 3D) pada sifat-sifat bangun datar pada kelas III SD N 3 Ngeling. Penelitian tindakan kelas ini telah dilaksanakan di kelas III SD N 3 Ngeling dengan subjek penelitian 28 siswa dan peneliti sebagai guru. Analisis data yang digunakan adalah analisis data kuantitatif dan kualitatif. Hasil Penelitian menunjukkan adanya peningkatan kemampuan pemahaman matematis pada materi sifat-sifat bangun datar yang signifikan yang mencapai rata-rata presentase antara siklus I $(71,43 \%)$ dan siklus II $(82,14 \%)$. Rata-rata aktivitas belajar siswa mengalami peningkatan dari skor rata-rata 2,31 dengan kriteria cukup baik pada siklus I, mengalami peningkatan menjadi 2,53 pada siklus II dengan kriteria baik. Hasil keterampilan mengajar guru juga mengalami peningkatan dari skor rata-rata 3,07 dengan kriteria baik, meningkat menjadi skor rata-rata sebesar 3,35 pada siklus II dengan kriteria sangat baik
\end{abstract}

(C) 2018 Universitas Muria Kudus

\footnotetext{
${ }^{\bowtie}$ Alamat korespondensi:

Program Studi Pendidikan Matematika, Universitas Muria Kudus

Kampus UMK Gondangmanis, Bae Kudus Gd. L. lantai 1 Ruang 2 PO. BOX 53 Kudus

Tlp (0291) 438229 Fax. (0291) 437198

E-mail: 201433282@std.umk.ac.id
} 
Titin Safitri, Sucipto dan Henry Suryo Bintoro

Anargya: Jurnal Pendidikan Matematika, Vol. 1 No.2, Oktober 2018

\section{PENDAHULUAN}

Sekolah sebagai lembaga pendidikan formal merupakan salah satu lembaga sosial budaya dalam masyarakat sehingga harus mampu mengikuti dan menganggapi arus perubahan cepat yang terjadi di masyarakat termasuk salah satunya yaitu perkembangan teknologi. Sekolah sebagai tempat atau wadah berkembangnya anak juga diharapkan mampu menjembatani atau memfasilitasi perkembangan anak secara optimal, dengan kata lain anak diharapkan mampu mengembangkan kemampuan dirinya semaksimal mungkin untuk menentukan arah perkembangannya tanpa ada paksaan dari pihak-pihak tertentu kebijakan di sekolah. Pada hakikatknya pendidikan adalah upaya sadar dari suatu masyarakat dan pemerintah suatu negara untuk menjamin kelangsungan hidup dan kehidupan generasi penerusnya, selaku warga masyarakat, bangsa dan negara, secara berguna (berkaitan dengan kemampuan spiritual) dan bermakna (berkaitan dengan kemampuan kognitif dan psikomotorik) serta mampu mengatasi hari depan mereka yang senantiasa berubah dan selalu terkait dengan konteks dinamika budaya, bangsa, negara dan hubungan internasionalnya (Soegito, 2011:10).

Mata pelajaran dalam sekolah sangatlah penting dan salah satu mata pelajaran yang dipelajari siswa disekolah adalah matematika, mata pelajaran matematika dianggap siswa sebagai mata pelajaran yang sangat sulit karena berkaitan dengan simbol-simbol dan rumus yang banyak, padahal matematika berkaitan erat dengan lingkungan sekitar rumah dan kehidupan sehari-hari.

Hal ini sejalan dengan Puri (2017: 1) yang mengatakan bahwa "Matematika merupakan salah satu mata pelajaran yang sangat erat kaitanya dengan kegiatan sehari-hari manusia, baik dari hal yang sederhana sampai hal yang membutuh- kan suatu pemikiran lebih".

Pembelajaran matematika di sekolah dasar tidak hanya diarahkan pada peningkatan kemampuan siswa dalam berhitung, tetapi juga diarahkan juga kepada peningkatan kemampuan pemahaman matematis. Pemahaman matematis merupakan kemampuan yang berkenaan dengan memahami ide-ide matematika yang menyeluruh dan fungsional (Fahrudhin, 2018: 15). Siswa kurang tertarik dengan pelajaran matematika dan berpendapat bahwa matematika itu sulit, tidak dipungkiri matematika menjadi salah satu mata pelajaran dengan tingkat kesulitan belajar yang paling banyak yang dialami siswa.
Oleh karena itu diperlukan penelusuran lebih dalam terhadap apa saja yang di alami siswa sehingga siswa mengalami kesulitan dalam mengerjakan soal pemahaman matematis. Tidak sedikit pula siswa sering mendapatkan kesulitan dalam menyelesaikan tugas matematika khususnya pada soal sifat-sifat bangun datar, sebab pada umumnya siswa hanya memahami macam-macam bangun datar, bahkan ada yang masih terbalik dengan nama macam-macam bangun datar.

Salah satu model yang dapat dikembangkan dalam pemahaman matematis adalah penerapan model Jigsaw. Menurut Lestari (2015: 48) model pembelajaran Jigsaw merupakan salah satu tipe pembelajaran kooperatif yang menitikberatkan pada kerjasama kelompok dalam kelompok kecil. Ciri khas pembelajaran ini dibandingkan dengan tipe kooperatif lainnya, yaitu adanya kelompok belajar dan kelompok ahli (expert-team). Selain menggunakan metode jigsaw, juga menggunakan permaian Ular tangga tiga dimensi (Ultra 3D) yang nantinya akan memperkuat pemahaman matematis siswa mengenai materi sifat-sifat bangun datar.

Penelitian ini bertujuan untuk mendiskripsikan peningkatan kemampuan pemahaman matematis, aktivitas belajar siswa, dan keteramnilan mengajar guru dalam mengelola pembelajaran matematika menggunakan model pembelajaran Jigsaw dengan media permainan ular tangga tiga dimensi (Ultra 3D).

\section{METODE PENELITIAN}

Penelitian tindakan kelas ini dilaksanakan di SD N 3 Ngeling Kecamatan Pecangaan Jepara. Subjek dalam penelitian tindakan kelas ini adalah siswa kelas III SDN 3 Ngeling Pecangaan Jepara pada tahun ajaran 2017/2018 sebanyak 28 siswa yang terdiri dari 17 siswa laki-laki dan 11 siswa perempuan. Variabel bebas atau independen merupakan variabel yang mempengaruhi atau yang menjadi sebab perubahannya atau timbulnya variabel dependen atau terikat (Sugiyono, 2010: 61). Dalam penelitian ini yang menjadi variabel bebas adalah model pembelajaran Jigsaw. Variabel terikat atau dependen merupakan variabel yang dipengaruhi atau yang menjadi akibat, karena adanya variabel bebas. Dalam penelitian ini yang menjadi variabel terikat adalah kemampuan pemahaman matematis, aktivitas belajar siswa dan keterampilan mengajar guru.

Rancangan (desain) Penelitian Tindakan Kelas (PTK) yang dipergunakan dalam 
penelitian ini adalah menggunakan model Kemmis dan Mc Taggart yang pelaksanaan tindakan dalam Penelitian Tindakan Kelas (PTK) meliputi empat alur (langkah): (1) perencanaan tindakan; (2) pelaksanaan tindakan; (3) observasi; dan (4) refleksi. Teknik pengumpulan datar yang digunakan dalam penelitian ini adalah teknik observasi, wawancara, tes dan dokumentasi. Analisis data yang digunakan adalah analisis data kuantitatif dan kualitatif. Data kuantitatif diperoleh dari tes tertulis siswa pada kemampuan pemahaman matematis yang diberikan disetiap akhir siklus. Sedangkan hasil kualitatif dari hasil pengematan keterampilan mengajar guru dan aktivitas belajar siswa.

Indikator keberhasilan penelitian ini yaitu: (1) pemahaman matematis dengan penerapan model jigsaw melalui permaian ular tangga tiga dimensi (Ultra 3D) pada sifat-sifat bangun datar mencapai ketuntasan belajar individual lebih dari 65 dan ketuntasan klasikal minimal 75\% dengan kriteria baik. (2) aktivitas belajar siswa dalam pelaksanaan pembelajaran dengan penerapan model jigsaw melalui permaian ular tangga tiga dimensi (Ultra 3D) pada sifat-sifat bangun datar minimal mencapai kriteria baik dengan skor ratarata lebih dari 2,5. (3) keterampilan mengajar guru dalam pelaksanaan pembelajaran dengan penerapan model jigsaw melalui permaian ular tangga tiga dimensi (Ultra 3D) pada sifat-sifat bangun datar minimal mencapai kriteria baik dengan skor rata-rata lebih dari 2,5.

\section{HASIL DAN PEMBAHASAN}

Penelitian ini diawali dari rendahnya pemahaman matematis siswa di kelas III SD N 3 Ngeling. Berdasarkan hasil wawancara dengan guru kelas III SD N 3 Ngeling, bahwa sebagian siswa masih bingung dan mengalami kesulitan dan cepat merasa bosan dalam mengukuti pembelajaran, hal ini dapat dilihat pada saat siswa mengerjakan soal evaluasi. Siswa masih banyak mengalami kesulitan dan hasil ulangan harian juga menunjukkan sebagian besar siswa belum mencapai ketuntasan. Rendahnya pemahaman matematis siswa pada mata pelajaran matematika terlihat pada hasil tes prasiklus.

Rata-rata nilai prasiklus materi sifat-sifat bangun datar yaitu 49,6. Dari 28 siswa, 18 $(64,29 \%)$ siswa belum mencapai kriteria ketuntasan belajar dan $10 \quad(35,71 \%)$ siswa mencapai kriteria ketuntasan belajar. Adapun hasil tes prasiklus siswa kelas III SDN 3 Ngeling sebagai berikut.
Berdasarkan kondisi awal tersebut peneliti melakukan penelitian tindakan kelas dengan menggunakan model pembelajaran Jigsaw untuk peningkatan pemahaman matematis siswa denga permainan ukat tangga tiga dimensi (ULTRA 3D) pada sifat-sifat bangun datar pada kelas III SDN 3 Ngeling.

Penelitian tindakan kelas ini memuat pembelajaran matematika materi sifat-sifat bangun datar. Pada siklus I dilaksanakan 2 pertemuan yaitu pada tanggal 9 April 2018 dan 10 April 2018 dengan alokasi waktu tiap pertemuan 2 x 35 menit, dengan materi sifat-sifat bangun datar persegi dan persegi panjang pada pertemuan 1 sedangkan pada pertemuan 2 dengan materi sifat-sifat bangun datar trapesium dan layang-layang.

Hasil kemampuan pemahaman matematis siswa siklus I setelah menggunakan model pembelajaran kooperatif tipe Jigsaw dikaetahui rata-rata hasil belajar matematika siswa pada siklus I kelas III SDN 3 Ngeling materi sifat-sifat bangun datar meningkat menjadi 68,11 dari nilai rata-rata prasiklus siswa hanya mencapai 49,64. Untuk mengetahui tingkat ketuntasan belajar siswa maka dilakukan analisis terhadap nilai tes evaluasi siklus I siswa dibandingkan dengan kriteria ketuntasan minimal, sehingga diketahui jumlah siswa yang tuntas dan belum tuntas akan disajikan pada tabel di bawah ini.

Tabel 1. Ketuntasan Kemampuan Pemahaman Matematis Siklus I

\begin{tabular}{|c|c|}
\hline Keterangan & Hasil \\
\hline Nilai rata-rata kelas & 68,11 \\
\hline Jumlah siswa tuntas KKM & 20 siswa $(71,43 \%)$ \\
\hline $\begin{array}{l}\text { Jumlah siswa tidak tuntas } \\
\text { KKM }\end{array}$ & 8 siswa $(28,57 \%)$ \\
\hline
\end{tabular}
juga mengalami peningkatan, dari yang semula berjumlah 18 siswa atau sebesar $64,29 \%$ menjadi 20 siswa atau sebesar $71,43 \%$. Sedangkan siswa yang belum mencapai ketuntasan menurun, dari yang semula berjumlah 10 siswa atau sebesar $35,71 \%$ menjadi 8 siswa atau sebejar $28,57 \%$. Hasil belajar siswa siklus I sebesar 71,53\% dinyatakan belum berhasil karena untuk memenuhi indicator keberhasilan setidaktidaknya $75 \%$ dari jumlah siswa harus sudah tuntas dengan hasil belajar sekurang-kurangnya memperoleh nilai 65 .

Hasil observasi aktivitas belajar siswa dalam menerapkan model pembelajaran kooperatif model Jigsaw dengan media permainan Ular Tangga Tiga Dimensi (ULTRA 3D) pada siklus I pertemuan 1 diperoleh total 
Titin Safitri, Sucipto dan Henry Suryo Bintoro

Anargya: Jurnal Pendidikan Matematika, Vol. 1 No.2, Oktober 2018

skor 61,75 dan skor rata-rata 2,21 dengan kriteria cukup baik, pada tabel di bawah ini.

Tabel 2. Hasil Observasi Aktivitas Belajar Siswa Siklus I

\begin{tabular}{lcc}
\hline \multirow{2}{*}{ Keterangan } & \multicolumn{2}{c}{ Siklus I } \\
& Pertemuan 1 & Pertemuan 2 \\
\hline Total Skor & 61,75 & 67,3 \\
Skor Rata-rata & 2,21 & 2,40 \\
Kriteria & Cukup Baik & Cukup Baik \\
Rata-rata Siklus & \multicolumn{2}{c}{2,3} \\
I & \multicolumn{2}{c}{ Cukup Baik } \\
Kriteria & \multicolumn{2}{c}{ Cuta } \\
\hline
\end{tabular}

Sedangkan pada siklus I Pertemuan 2 diperoleh total skor 67,3 dan skor rata-rata 2,40 dengan kriteria cukup baik. Rata-rata aktivitas belajar siswa pada siklus I yaitu 2,3 dengan kriteria cukup baik. Sehingga aktivitas belajar siswa pada siklus I belum memenuhi indicator keberhasilan dengan rata-rata lebih dari 2,5 pada kriteria baik. Hal tersebut menujukkan bahwa aktivitas belajar perlu ditingkatkan pada siklus ke II hingga mencapai rata-rata lebih dari 2,5 pada kriteria baik.

Hasil keterampilan mengajar guru dalam menerapkan model pembelajaran kooperatif model Jigsaw dengan media permainan Ular Tangga Tiga Dimensi (ULTRA 3D) pada siklus I pertemuan 1 diperoleh total skor 60 dan skor rata-rata 3 dengan kriteria baik. Sedangkan pada siklus I Pertemuan 2 diperoleh total skor 63 dan skor rata-rata 3,15 dengan kriteria baik. Rata-rata aktivitas belajar siswa pada siklus I yaitu 3,15 dengan kriteria baik. Sehingga keterampilan mengajar guru pada siklus I sudah memenuhi indikator keberhasilan dengan rata-rata lebih dari 2,5 pada kriteria baik. Meskipun pada siklus I keterampilan mengajar guru sudah mencapai indicator keberhasilan, namun hal tersebut masih perlu ditingkatkan pada siklus ke II. Pada tabel di bawah ini

Tabel 3. Hasil Keterampilan Mengajar Guru Siklus I

\begin{tabular}{lcc}
\hline \multirow{2}{*}{ Keterangan } & \multicolumn{2}{c}{ Siklus I } \\
& Pertemuan 1 & Pertemuan 2 \\
\hline Skor Rata-rata & 3 & 3,15 \\
Kriteria & Baik & \multicolumn{2}{c}{ Baik } \\
Rata-rata $\quad$ Klasikal & \multicolumn{2}{c}{3.08} \\
Siklus I & \multicolumn{2}{c}{ Baik } \\
Kriteria & \multicolumn{2}{c}{} \\
\hline
\end{tabular}

Penelitian tindakan kelas ini memuat pembelajaran matematika materi sifat-sifat bangun datar. Pada siklus I dilaksanakan 2 pertemuan yaitu pada tanggal 16 April 2018 dan 17 April 2018 dengan alokasi waktu tiap pertemuan $2 \times 35$ menit, dengan materi sifat-sifat bangun datar jajar genjang dan belah ketupat pada pertemuan 1 sedangkan pada pertemuan 2 dengan materi sifat-sifat bangun datar segitiga dan lingkaran.

Hasil kemampuan pemahaman matematis siswa siklus I setelah menggunakan model pembelajaran kooperatif tipe Jigsaw diketahui rata-rata nilai hasil belajar matematika siswa pada siklus II kelas III SDN 3 Ngeling materi sifat-sifat bangun datar meningkat menjadi 80,29 dari nilai rata-rata siklus I siswa hanya mencapai 68,11. Siswa yang telah mencapai ketuntasan juga mengalami peningkatan, dari yang semula berjumlah 20 siswa atau sebesar 71,43\% menjadi 23 siswa atau sebesar 78,57\%. Sedangkan siswa yang belum mencapai ketuntasan menurun, dari yang semula berjumlah 8 siswa atau sebesar $28,57 \%$ menjadi 5 siswa atau sebesar $17.86 \%$. Jumlah siswa yang tuntas dan belum tuntas akan disajikan pada tabel 4di bawah ini.

Tabel 4. Ketuntasan Kemampuan Pemahaman Matematis Siswa Siklus II

\begin{tabular}{|c|c|}
\hline Keterangan & Hasil \\
\hline Nilai rata-rata kelas & 80,43 \\
\hline Jumlah siswa tuntas KKM & 23 siswa $(82,14 \%)$ \\
\hline $\begin{array}{l}\text { Jumlah siswa tidak tuntas } \\
\text { KKM }\end{array}$ & 5 siswa $(17,86 \%)$ \\
\hline
\end{tabular}

Siswa yang mendapat nilai di atas KKM da 23 siswa, dan siswa yang mendapat nilai di bawah KKM ada 5 siswa. Ini berarti ketuntasan belajar siswa mencapai $82,14 \%$ atau $82 \%$, sedangkan siswa yang tidak tuntas sebesar $17,86 \%$ atau $18 \%$. Hasil belajar siswa siklus I sebesar $82,14 \%$ dinyatakan sudah berhasil karena untuk memenuhi indicator keberhasilan setidaktidaknya $75 \%$ dari jumlah siswa harus sudah tuntas dengan hasil belajar sekurang-kurangnya memperoleh nilai 65 .

Hasil observasi aktivitas belajar siswa dalam menerapkan model pembelajaran kooperatif model Jigsaw dengan media permainan Ular Tangga Tiga Dimensi (ULTRA 3D) pada siklus II pertemuan 1 diperoleh total skor 69,25 dan skor rata-rata 2,47 dengan kriteria cukup baik, pada tabel di bawah ini.

Tabel 5. Hasil Observasi Aktivitas Belajar Siswa Siklus II

\begin{tabular}{lcc}
\hline \multirow{2}{*}{ Keterangan } & \multicolumn{2}{c}{ Siklus II } \\
\cline { 2 - 3 } & Pertemuan 1 & Pertemuan 2 \\
\hline Skor Rata-rata & 2,47 & 2,60 \\
Kriteria & Cukup Baik & Baik \\
Rata-rata Siklus I & \multicolumn{2}{c}{2,53} \\
Kriteria & \multicolumn{2}{c}{ Baik } \\
\hline
\end{tabular}

Sedangkan pada siklus II Pertemuan 2 diperoleh total skor 72,9 dan skor rata-rata 2,60 dengan kriteria baik. Rata-rata aktivitas belajar 
Titin Safitri, Sucipto dan Henry Suryo Bintoro

Anargya: Jurnal Pendidikan Matematika, Vol. 1 No.2, Oktober 2018

siswa pada siklus II yaitu 2,53 dengan kriteria baik. Sehingga aktivitas belajar siswa pada siklus II dinyatakan berhasil memenuhi indicator keberhasilan dengan rata-rata lebih dari 2,5 pada kriteria baik. Hal tersebut menujukkan bahwa aktivitas belajar pada siklus II mengalami peningkatan dari siklus I dengan rata-rata sebasar 2,3 dengan kriteria cukup baik yang belum memenuhi indicator keberhasilan dengan ratarata lebih dari 2,5 .

Hasil keterampilan mengajar guru dalam menerapkan model pembelajaran kooperatif model Jigsaw dengan media permainan Ular Tangga Tiga Dimensi (ULTRA 3D) pada siklus II pertemuan 1 diperoleh total skor 65 dan skor rata-rata 3,25 dengan kriteria sangat baik. Sedangkan pada siklus II pertemuan 2 diperoleh total skor 69 dan skor rata-rata 3,45 dengan kriteria sangat baik. Rata-rata aktivitas belajar siswa pada siklus I yaitu 3,35 dengan kriteria sangat baik. Sehingga keterampilan mengajar guru pada siklus II sudah memenuhi indikator keberhasilan dengan rata-rata lebih dari 2,5 pada kriteria baik, pada tabel di bawah ini.

Tabel 6. Hasil Keterampilan Mengajar Guru Siklus II

\begin{tabular}{lcc}
\hline \multirow{2}{*}{ Keterangan } & \multicolumn{2}{c}{ Siklus II } \\
\cline { 2 - 3 } & Pertemuan 1 & Pertemuan 2 \\
\hline Skor Rata-rata & 3,25 & 3,45 \\
Kriteria & Sangat Baik & Sangat Baik \\
Rata-rata & Klasikal & \multicolumn{2}{c}{3.35} \\
Siklus II & \multicolumn{2}{c}{ Sangat Baik } \\
Kriteria & \multicolumn{2}{c}{} \\
\hline
\end{tabular}

Hasil penelitian dan analisis data yang ada menunjukkan bahwa penerapan model jigsaw dapat meningkatkan pemahaman matematis, aktivitas belajar siswa dan keterampilan mengajar guru dengan permainan ular tangga tiga dimensi (Ultra 3D) pada sifat-sifat bangun datar pada kelas III SD N 3 Ngeling. Peningkatan tersebut ditunjukkan setelah dilakukan tindakan pada siklus I dan siklus II yang masing-masing 2 pertemuan.

\section{Pemahaman Matematis Siswa}

Upaya peningkatan pemahaman matematis kelas III dilakukan berdasarkan hasil pra siklus atau konsidisi awal siswa hanya menunjukkan hasil rata-rata sebesar 49,64 dengan ketuntasan klasikal sebesar 64,29\% atau sejumlah 18 siswa yang tuntas, dengan hasil ini menunjukkan bahwa siswa kelas III baru sampai pada dimana siswa hanya sekedar menghafal bentuk-bentuk banggun datar dan belum memahami sifat-sifat bangun datar. Padahal Ani (2017: 972) menjelaskan bahwa pemahaman matematis merupakan pemahaman siswa terhadap suatu konsep materi pelajaran itu sendiri dan bukan hanya sekedar menghafal, tentu saja masing-masing siswa mempunyai berbedaan dalam mpemahaman konsepnya.

Pemahaman matematis ini sangat penting karena pemahaman matematis merupakan syarat untuk memahammi konsep lainnya, siswa yang tidak dapat memahami konsep matematis maka ada kemungkinan siswa tidak dapat memecahlan masalah, bernalar, dan menghubungkan dengan kehidupan sehari-hari. Oleh sebab itu, kemampuan pemahaman matematis perlu di kembangkan lagi dalam pembelajaran matematika. Dalam pembelajaran guru sudah menggunakan model pembelajaran dan media gambar namun selama kegiatan pembelajaran siswa cenderung pasif dan kemampuan matematis siswa rendah. Berdasarkan kondisi tersebut peneliti melakukan penelitian tindakan kelas untuk meningkatkan kemampuan matematis siswa dengan menerapkan model pembelajaran Jigsaw menggunakan permainan Ular Tangga Tiga dimensi (ULTRA 3D) pada sifat-sifat banun datar pada kelas III SDN 3 Ngeling.

Pada siklus I, kemampuan matematis siswa memperoleh nilai rata-rata sebsesar 68,11 dengan ketuntasan klasikal siswa 71,43 \% atau sejumlah 20 siswa yang tuntas. Nilai rata-rata siswa sudah memenuhi indikator keberhasilan yaitu $\geq 65$, namun ketuntasan klasikal belum melebihi ketuntasan klasikal yang peneliti tentukan yakni $75 \%$. Hasil yang diperoleh siswa pada siklus I menunjukan bahwa siswa kelas III sudah memiliki kemampuan yang baik dalam pemahaman matematis yang di pelajari, dan menyelesaikan masalah dalam pembelajaran matematika.

Kemampuan yang dicapai siswa tersebut sesuai dengan hakikat kemampuan matematis menurut Fauziyah (2017: 912) yang menjelaskan bahwa untuk menyelesaikan masakah dalam pembelajaran matematika dibutuhkan kemampuan pemahaman untuk memecahkannya, karena apabila telah paham dengan masalah yang diberikan maka siswa akan lebih mudah untuk menyelesaikan masalah yang dihadapinya. Oleh karena itu guru mengembangkan pembelajaran yang dapt meningkatkan kemampuan pemahaman matematis siswa dengan membuat pembelajaran yang menyenangkan dan juga pembelajaran yang berhubungan dengan kehidupan sehari-hari, dengan begitu siswa dapat membangun pengetahuan barunya dengan pengetahuan yang dimilikinya melalui pengalaman. 
Kemampuan pemahaman matematis yang dicapai siswa pada siklus I terdapat 8 siswa yang memeperoleh nilai dibawah KKM sebesar 65 yaitu ARM, ASR, AK, AEP, EPRR, MRAA, NAN dan SAS. Beberapa siswa masih kebingungan dalam mengerjakan lembar kerja siswa saat diskusi, karena siswa langsung mengisi lembar kerja siswa sebelum melakukan permainan ular tangga tiga dimensi. Selain itu siswa kurang bekerja sama dengan kelompoknya karena siswa ingin segera melakukan permainan ular tangga tiga dimensi.

Pada pembelajaran siklus I peneliti memperoleh temuan bahwa pada tahap diskusi beberapa siswa, yaitu ATP, ADKR, ARA, AFD, RR, CAR, DH mengalami kesulitan dalam mengerjakan lembar kerja siswa karena ketua dari kelompok belum bisa mengkondisikan anggota kelompoknya untuk saling bekerjasama antara anggota satu dengan anggota yang lainnya sehingga timbul masalah saat kegiatan diskusi berlangsung, salah satunya ada siswa yang tidak ikut melakukan permainan ular tangga tiga dimensi karena siswa tersebut kurang antusias jika mengerjakan soal dengan cara berkelompok. Hal ini terlihat dari hasil diskusinya bahwa kelompok tersebut belum dapat menyelesaikan lembar kerja siswa pada waktu yang telah ditentukan peneliti, sedangkan kelompok yang lain sudah dapat menyelsaikan lembar kerja siswa dengan waktu yang telah di tentukan peneliti dengan begitu siswa dapat memahami semua sifat-sifat bangun datar. Dalam pembelajaran Jigsaw siswa tidak hanya dituntut untuk aktif dalam berdikusi kelompok memperlajari materinya tetapi juga mengajarkan kepada teman-temannya.

Peningkatan pemahaman matematis yang dicapai siswa kelas III SDN 3 Ngeling pada siklus I terjadi karena berkaitan dengan tindakan berupa penerapan model pembelajaran Jigsaw dengan menggunakan permainan ular tangga tiga dimensi (Ultra 3D) yang dilakukan. Berdasarkan analisis pemahaman matematis yang dilakukan pada siklus I, terliha bahwa penerapan model Jigsaw dengan menggunakan permainan ular tangga tiga dimensi (Ultra 3D) dalam pembelajaran matematika terbukti mampu meningkatkan pemahaman matematis siswa.

Pembelajaran siklus II, peneliti memperbaiki pembelajaran dengan memperhatikan kekurangan-kekurangan yang terdapat pada siklus I. Pada siklus II dilaksanakan berdasarkan refleksi siklus I yang belum dikatam berhasil, karena ketuntasan klasikal siklus I belum mencapai ketuntasan klasikal yang ditentukan yaitu $75 \%$ menjadi penyebab belum berhasilnya penelitian ini, untuk itu perlu dilanjut dengan penelitin siklus II. Pada siklus II peneliti memaksimalkan pembelajaran dengan cara memberikan menjelaskan kembali tata cara permainan ular tangga tiga dimensi secara tepat.

Hasil belajar kemampuan matematis siswa pada siklus II menunjukkan adanya peningkatan denga nilai rata-rata sebesar 80.43 dan nilai ketuntasan klasikal sebesar $82,14 \%$. Pada siklus II, siswa sudah paham dengan instruksi guru yakni tata cara permainan ulat tangga tiga dimensi secara tepat yang dilakukan pada saat kegiatan diskusi untuk mengerjaka lembar kerja siswa bersama anggota kelompok. Nilai rata-rata dan persentase ketuntasan belajar secara klasikal siswa meningkat di setiap siklusnya. Hal ini dikarenakan pembelajaran dengan menerapkan model pembelajaran koopetarif tipe jigsaw dengan mengaitkan materi dengan permainan sehingga siswa lebih mudah memahami konsep materi yang diajarkan.

Analisis indikator pemahaman matematis yang dilakukan terlihat bahwa persentase rata-rata yang dicapai siswa pada setiap siklus mengalami peningkatan. Adapun uraian peningkatan kemampuan siswa kelas III pada setiap indikator pemahaman matematis adalah sebagai berikut.

a. Mengidentifikasi berbagai sifat bangun datar Indikator pertama dalam pemahaman matematis adalah mengidentifikasi berbagai sifat bangun datar, dengan hal ini siswa harus dapat mendeskripsikan pengertian dari berbagai bangun datar dan menyebutkan sifat-sifat bangun datar. untuk mempermudah siswa untuk mengidentifikasi berbagai sifat bangun datar guru mengaitkannya dengan benda secara konkrit yang ada disekitarnya.

b. Memahami sifat-sifat bangun datar

Indikator selanjutnya dalam pemahaman matematis adalah memahami sifat-sifat bangun datar, dalam memahami sifat-sifat bangun datar guru meminta siswa untuk menunjuk benda bangun datar yang ada di dalam kelas serta menjelaskan sifat-sifat bangun datar sesuai benda yang ditunjuk tersebut. Dengan begini siswa dapat memahami sifat-sifat bangun datar dengan menjelaskan secara langsung melaui benda tersebut.

c. Menerjemahkan dan menafsirkan berbagai sifat-sifat bangun datar Indikator menerjemahkan dan menafsirkan berbagai sifat-sifat bangun datar siswa, dalam hal ini siswa menerjemahkan dan mendefinisikan berbagai bangun datar dan siswa menggambar berbagai bangun datar dengan 
tepat. Dengan hal ini selain siswa dapat menejaskan berbagai bangun datar tersebut, siswa juga dapat menggambar berbagai bentuk bangun datar dengan baik. Namun pada saat siswa menggambar bangun datar masih kurang rapi meski sudah menggunakan penggaris dan guru membimbung siswa agar siswa dapat menggambar bangun datar dengan tepat.

d. Membuat suatu perkiraan berbagai bangun datar pada kehidupan sehari-hari

Pada indikator membuat suatu perkiraan berbagai bangun datar pada kehidupan seharihari, disini siswa menyebutkan sebanyakbanyaknya benda disekitarnya yang sesuai dengan bangun datar yang dipelajari. Namun dalam hal ini siswa masih kesulitan menyebutkan contoh benda yang berbentuk jajar genjang dan trapesium, sehingga guru harus memberikan contoh terlebih dahulu agar siswa mendapat inspirasi untuk menyebutkan benda yang lain.

Berdasarkan hasil uraian di atas maka dapat disimpulkan bahwa evaluasi siklus I dan siklus II mengalami peningkatan. Hal ini terjadi karena di pengaruhi oleh model pembelajaran Jigsaw berbantuan media permainan ular tangga tiga dimensi (Ultra 3D) dapat meningkatkan kemampuan pemahaman matematis siswa. Dari model pembelajaran Jigsaw dapat dilihat bahwa model ini mempunyai ciri khas adanya kelompok asal dan kelompok ahli. Setelah siswa di bagi dalam beberapa kelompok, kemudian pembagian subbab pada setiap kelompok dan mempelajari subbab yang telah ditugaskan, selanjutnya setiap kelompok menunjuk salah satu anggotanya agar mewakili kelompoknya untuk bergabung dengan perwakilan dari kelompok lainnya dan membentuk kelompok ahli, sedangkan anggota yang lain disebut dengan kelompok asal. Setelah mendalami materi materi melalui diskusi dengan kelompok ahli, kemudian siswa kembali ke kelompok asal untuk berbagi materi dan diskusi kelompok hingga mempersentasikan hasil diskusi.

Berdasarkan proses tersebut dapat menstimulus siswa untuk meningkatkan kemampuan pemahaman matematis siswa. Uraian tersebut diperkuat oleh Lestari (2015:48) model pembelajaran Jigsaw merupakan salah satu tipe pembelajaran kooperatif yang menitiberatkan pada kerjasama kelompok dalam kelompok kecil, ciri khas pembelajaran ini dengan di bandingkan dengan tipe kooperatif lainnya yaitu adanya kelompok belajar dan kelompok ahli (expert-team).

Selain peningkatan kemampuam pemahaman matematis siswa dipengaruhi oleh model pembelajaran Jigsaw juga dipengaruhi oleh media permainan ular tangga tiga dimensi (Ultra 3D). Media permainan ular tangga tiga dimensi (Ultra 3D) digunakan oleh peneliti untuk dijadikan sebagai pengantar untuk menjelaskan materi pembelajaran khususnya sifat-sifat bangun datar. Media permainan ular tangga tiga dimensi (Ultra 3D) yaitu alat peraga yang dapat digunakan sebagai alat untuk mendidik, menghibur dan membangun komunikasi interaktif antar pemain.

Maka dari itu dengan adanya media pemainan ular tangga terbukti bahwa hasil penelitian evaluasi siklus I dan siklus II sudah berhasil dan mencapai di atas kriteria yang ditentukan. Penjelasan tersebut diperkuat oleh Nachiappan dan Wulanyani dalam Sudarmika (2018: 21) yang menyatakan bahwa permainan ular tangga juga bisa digunakan sebagai alat untuk mendidik, menghibur, dan membangun komunikasi interaktif antar pemain.

Berdasarkan uaraian peningkatan pemahaman matematis tersebut dapat disimpulkan bahwa melalui tindakan yang dilakukan menggunakan model pembelajaran Jigsaw dengan media permainan ular tangga tiga dimensi (Ultra 3D) pada pelajaran matematika dapat meningkatkan pemahaman matematis siswa kelas III SDN 3 Ngeling khususnya pada materi sifat-sifat bangun datar.

\section{Aktivitas Belajar Siswa}

Peningkatan Pemahaman konsep matematis yang dicapai oleh siswa kelas III SDN 3 Ngeling tidak terlepas dari aktivitas-aktivitas yang dilakukan siswa dalam kegiatan pembelajaran. Kegiatan belajar mengajar tidak luput dari aktivitas belajar siswa yang dilakukan di dalam kelas maupun dilakukan diluar kelas, dalam proses pembelajaran pasti melibatkan berbagai aktivitas siswa. Hal ini sejalan dengan Djamarah (2011: 38) yang menyatakan bahwa belajar bukanlah berproses dalam kehampaan tidak pula pernah sepi dari berbagai aktivitas karena aktivitas belajar siswa itu selalu berhubungan dengan masalah belajar, menulis, mencatat, memandang, membaca, mengungat, berpikir, latihan atau praktek dan lain sebagainya.

Aktivitas belajar siswa yang terjadi pada saat pembelajaran berlangsung terdapat banyak kejadian - kejadian yang terjadi mulai dari hal yang sederhana sampai hal yang menuntut siswa harus bekerja keras untuk mencapai tujuan pembelajaran. Hal ini sejalan dengan Paul D, Dierich dalam Hamalik (2009: 172) menyatakan kegiatan belajar dibagi dalam 8 kelompok diantaranya (1) Kegiatan-kegiatan visual, (2) Kegiatan-kegiatan lisan (oral), (3) Kegiatan- 
Titin Safitri, Sucipto dan Henry Suryo Bintoro

Anargya: Jurnal Pendidikan Matematika, Vol. 1 No.2, Oktober 2018

kegiatan mendengar, (4) Kegiatan-kegiatan menulis, (5) Kegiatan-kegiatan menggambar, (6) Kegiatan-kegiatan metric, (7) Kegiatan-kegiatan mental, (8) Kegiatan-kegiatan emosional.

Skor yang diperoleh siswa pada siklus I pertemuan 2 menunjukkan rata-rata klasikal sebesar 2,40. Hasil tersebut mengalami peningkatan sebesar 0,19 dari hasil perolehan pda pertemuan 1 yang hanya peroleh skor sebesar 2,40. Peningkatan aktivitas belajar siswa tidak terlepas dari penerapan model pembelajaran Jigsaw yang telah dilakukan dalam kegiatan pembelajaran. Hasil tersebut sesuai dengan pendapat Adam dalam Widayanti (2017: 80) mengungkapkan dalam penelitiannya bahwa model pembelajaran Jigsaw secara signifikan dapat meningkatkan prestasi akademik dan aktivitas belajar siswa serta meningkatkan kepuasan siswa dalam pengalaman belajar. Hal ini disebbkan karena setiap siswa memiliki tanggung jawab untuk mempelajari sub bab materi dan mengajarkannya pada temannya, sehingga mau tidak mau siswa harus aktif dalam mempelajari materi tersebut baik secara individu maun secara kelompok.

Peningkatan aktivitas belajar siswa yang dicapai juga disebabkan oleh media permaina ular tangga tiga dimensi (Ultra 3D) yang digunakan. Melalui penggunaan media permainan ukar tangga tiga dimensi (Ultra 3D) terlihat siswa kelas III SDN 3 Ngeling lebih aktif dalam memahmi konsep yng dipelajari. Hal ini sejalan dengan Sanjaya (2007: 163) yang menjelaskan media digunakan dalam bidang pengajaran atau pendidikan sehingga istilahnya menjadi media pendidikan atau media pembelajaran dimana media bukan hanya berupa alat atau bahan saja, akan tetapi hal-hal lain yang memungkinkan siswa dapat mempeoleh pengetahuan.

Peningkatan aktivitas belajar siswa kelas III SDN 3 Ngeling pada siklus II mengalami peningkatan kearah yang lebih baik. Hal itu terlihat pada hasil perhitungan rata-rata skor aktivitas belajar siswa pada siklus II pertemuan 1 menunjukkan rata-rata klasikal sebesar 2,47 dengan kriteria cukup baik sedangkan pada siklus II pertemuan 2 menunjukkan rata-rata klasikal sebesar 2,61 dengan kriteria baik. Aktivitas belajar siswa secara umum dalam pembelajaran siklus II bsudah memenuhi kriteria yang di tentukan peneliti hingga mencapai rata-rata skor $\geq 25$ pada kriteria baik. Jika melihat aktivitas belajar siswa pada di setiap indikator yang telah dilakukan pada siklus I dan siklus II akan dijabarkan sebagai berikut.

\section{Kegiatan-kegiatan visual}

Dalam indikator aktivitas belajar siswa pada kegiatan-kegiatan visual yang jabarkan dalam tiga aspek yaitu memperhatikan penjelasan guru, memperhatikan alat peraga yang dijelaskan guru dan memperhatikan cara menggunakn media. Pada ketiga aspek tersebut siswa sudah memperhatikan penjelasan guru dengan baik pada setiap pertemuan di setiap siklus I dan siklus II namun terdapat beberapa siswa yang tidak memperhatikan penjelasan guru sehingga guru harus menegur siswa agar siswa tersebut memperhatikan penjelasan guru dengan baik.

2. Kegiatan-kegiatan lisan (Oral)

Pada indikator aktivitas belajar siswa pada kegiatan-kegiatan lisan (Oral) yang jabarkan dalam empat aspek yakni mengajukan pertanyaan terhadap materi yang belum jelas, mengemukakan pendapat pada saat diskusi, berdiskusi dengan kelompok, dan mengemukakan pendapat ketika pembelajaran berlangsung. Pada keempat aspek tersebut siswa sudah berani mengemukakan pendapat pada saat diskusi dengan baik meskipun pada saat pembelajaran berlangsung mengenai materi yang belum jelas namun, di awal pertemuan siswa masih belum berani untuk mengemukakan pendapat dan setelah beberapa kali pertemuan siswa sudah berani mengemukakan pendapat.

3. Kegiatan-kegiatan Mendengarkan

Pada indikator aktivotas belajar siswa pada kegiatan-kegiatan mendengarkan yang dijabarkan dalam dua aspek yakni mendengarkan penjelasan permainan dan mendengarkan percakapan pada saat diskusi. Pada tahap ini siswa sudah baik dalam mendengarkan dan memahami penjelasakn guru pada setiap pertemuan, namun siswa kurang menanggapi dengan baik ketika anggota kelompoknya mengemukakan pendapat pada saat diskusi kelompok maupun pada saat pembelajaran berlangsung. dan disini peran guru sangat dibutuhkan agar siswa mendengarkan dan menghargai temannya ketika mengemukakan pendapat.

4. Kegiatan-kegiatan menulis

Pada indikator aktivitas belajar siswa pada kegiatan-kegiatan menulis yang jabarkan dalam tiga aspek yakni mengerjakan lembar kerja siswa, menulis materi pelajaran dan membuat rangkuman pelajaran. Pada ketiga aspek ini indikator kegiatan menulis dalam mengerjakan lembar kerja siswa sudah baik sesuai dengan petunjuk yang diberikan guru meskipun tulisan siswa masih belum menggunakan penggunaan EYD (ejaan yang 
Titin Safitri, Sucipto dan Henry Suryo Bintoro

Anargya: Jurnal Pendidikan Matematika, Vol. 1 No.2, Oktober 2018

disempurnakan) tetapi tulisan siswa masih dipahami oleh guru.

5. Kegiatan-kegiatan menggambar

Pada indikator aktivitas belajar siswa pada kegiatan-kegiatan menggambar yang jabarkan dalam dua aspek yakni menggambar bangun datar dan membuat pola bangun datar. Pada kedua aspek ini siswa membuat pola berbagai bangun datar sesuai materi yang diajarkan, namun hasil siswa dalam membuat pola dan menggambar bangun datar masih belum tepat dan kurang rapi meskipun pada saat menggambar bangun datar sudah menggunakan penggaris. Sehingga guru membimbing siswa untuk menggambar bangun datar hingga siswa dapat membuat bangun datar secara mandiri tanpa bantuan bimbingan dari guru.

6. Kegiatan-kegiatan metric

Pada indikator aktivitas belajar siswa pada kegiatan-kegiatan menggambar yang jabarkan dalam dua aspek yakni bekerja sama dengan kelompok dan melakukan permainan sesuai dengan petunjuk yang diberikan. Pada tahap ini siswa sudah melakukan permainan ular tangga sesuai dengan mpenjelasan guru dan melakukan permainan ular tangga tiga dimensi (Ultra 3D) sesuai dengan tata cara petunjuk mengerjakan lembar kerja siswa sesuai yang dijelaskan oleh guru. Namun pada saat kerja kelompok, ketua kelompok mengeluhkan ada anggotanya yang tidak mndengarkan arahan dari ketua kelompok sehinngga meminta guru untuk menegur dan menasihati agar kepad anggota kelompoknya agar mendengarkan arahan dari ketua kelompoknya.

7. Kegiatan-kegiatan mental

Pada indikator aktivitas belajar siswa pada kegiatan-kegiatan mental yang jabarkan dalam dua aspek yakni memecahkan masalah dan mengingat kembali materi pelajarn yang telah dijelaskan. Pada tahap ini siswa dalam memecahkan dan mengingat materi cukup baik, namun di saat memecahkan masalah pada mengerjakan lembar kerja siswa masih kebingungan dengan cara menyelesaiakn soal tersebut sehingga guru harus menjelaskan kembali petunjuk pengerjaan lembar kerja siswa dengan menggunakan bahasa yang mudah dipahami.

8. Kegiatan-kegiatan emosional

Pada indikator aktivitas belajar siswa pada kegiatan-kegiatan emosional yang jabarkan dalam dua aspek yakni menghargai pendapat orang lain dan jujur dalam melakukan permainan dengan kelompoknya. Pada aspek ini sudah mampu untuk menghargai pendapat orang lain ,namun pada saat diskusi dan mengerjakan lembar kerja siswa terjadi disalah satu kelompok bahwa kelompok tersebut bermain curang dengan langsung mengerjakan lembar kerja siswa tanpa melakukan permainan ular tangga tiga dimensi (Ultra 3D) sesuai dengan petunjuk pengerjaan lembar kerja siswa, sehingga guru mengambil tindakan dengan menegur kelompok tersebut agar mengerjakan lembar kerja siswa sesuai dengan petunjuk yang dijelaskan oleh guru.

Berdasarkan hasil uraian di atas maka dapat disimpulkan bahwa model pembelajaran Jigsaw dengan media permainan ular tangga tiga dimensi (Ultra 3D) sangat mempengaruhi aktivitas belajar siswa yang lebih baik. Hal ini terjadi karena di pengaruhi oleh model pembelajaran Jigsaw berbantuan media permainan ular tangga tiga dimensi (Ultra 3D) dapat meningkatkan kemampuan pemahaman matematis siswa. Dari model pembelajaran Jigsaw dapat dilihat bahwa model ini mempunyai ciri khas adanya kelompok asal dan kelompok ahli. Setelah siswa di bagi dalam beberapa kelompok, kemudian pembagian subbab pada setiap kelompok dan mempelajari subbab yang telah ditugaskan, selanjutnya setiap kelompok menunjuk salah satu anggotanya agar mewakili kelompoknya untuk bergabung dengan perwakilan dari kelompok lainnya dan membentuk kelompok ahli, sedangkan anggota yang lain disebut dengan kelompok asal. Setelah mendalami materi materi melalui diskusi dengan kelompok ahli, kemudian siswa kembali ke kelompok asal untuk berbagi materi dan diskusi kelompok hingga mempersentasikan hasil diskusi. Jadi, dalam model pembelajaran Jigsaw kekompakan siswa untuk saling bekerjasama pada saat diskusi antara anggota siswa saling ketergantungan. Sehingga hal inilah yang sesuai diharapkan guru agar aktivitas belajar siswa semakin meningkat.

Peningkatan hasil aktivitas belajar juga dipengaruhi oleh penggunaan media, dalam penelitian ini menggunakan media permainan ular tangga tiga dimensi (Ultra 3D). Dengan adanya alat peraga yang dapat memudahkan guru untuk menjelaskan materi yang diajarkan dan sebaliknya siswa akan lebih mudah memahami materi yang telah dipelajari. Penjelasan tersebut diperkuat oleh Arsyad (2017: 9) alat peraga adalah media alat bantu pembelajaran dan segala macam yang digunakan untuk memperagakan materi pelajaran.

Berdasarkan uraian peningkatan aktivitas belajar siswa tersebut dapat disimpulkan bahwa melalui tindakan yang dilakukan yaitu dengan penerapan model 
Titin Safitri, Sucipto dan Henry Suryo Bintoro

Anargya: Jurnal Pendidikan Matematika, Vol. 1 No.2, Oktober 2018

pembelajaran Jigsaw dengan permainan ular tangga tiga dimensi (Ultra 3D) dalam kegiatan pembelajaran matematika dapat meningkatkan aktivitas belajar.

\section{Keterampilan Mengajar Guru}

Pada umumnya proses kegiatan pembelajaran dilakukan oleh dua subjek, yaitu guru sebagai pendidik dan siswa sebagai peserta didik. Sebagai pendidik guru memberikan berbagai pengetahuan kepada siswa dalam proses kegiatan pembelajaran, khususnya pengetahuan tentang materi sifat-sifat bangun datar. Proses Instruktif yang dilakukan peneliti terhadap siswa seuai dengan pengajaran menurut Suprijono (2013: 12) yang menjelaskan bahwa perbuatan atau cara mengajarkan diterjemahkan sebagai kegiatan guru mengajari peserta didik, guru menyampaikan pengetahuan kepada peserta didik dan peserta didik sebagai pihak penerima dan pengejaran seperti ini merupakan proses instruktif.

Pelaksanaan pembelajaran yang peneiti lakukan terdiri dari 6 tahap kegiatan inti sesuai dengan langkah-langkah model pembelajarn Jigsaw yaitu; (1) pembelntukan kelompok, (2) pembangian subbab, (3) penugasan subbab, (4) pembinaan kelompok ahli, (5) diskusi, (6) kuis.

Hasil observasi keterampilan mengajar guru menunjukkan bahwa keterampilan guru dalam mengajar pada setiap pertemuan selalu mengalami peningkatan. Pada siklus I pertemuan 1 di peroleh skor rata-rata 3 dengan kriteria baik dan pada siklus I pertemuan 2 memperoleh skor rata-rata sebesar 3,5 dengan kriteria baik. Hasil tersebut mengalami peningkatan pada siklus II pertemuan 1 di peroleh skor rata-rata 3,25 dengan kriteria baik dan pada siklus II pertemuan 2 menunjukkan skor rata-rata sebesar 3,45 dengan kriteria sangat baik. Skor yang diperoleh setiap siklus merupakan jumlah sari skor setip indikator pengamatan mengajar guru meliputi 8 keterampilan dalam mengajar yaitu: (1) keterampilam bertanya, (2) keterampilan memberi penguatan, (3) keterampilan mengajar kelompok kecil dan perorangan, (4) keterampilan menjelaskan, (5) keterampilan mebuka dan menutup pelajaran, (6) keterampilan mebimbing diskusi kelompok kecil, (7) keterampilan mengelola kelas, (8) keterampilan mengadakan variasi.

Keterampilan mebuka dan menutup pelajaran yang dimiliki peneliti pada setiap pertemuan sudah baik. Siswa sudah dipersiapkan secara fisik dan spikis uuntuk menerima pelajaran, peneliti juga sudah menyampaikan materi yang diajarkan, menyampaikan rencana kegiatan, dan menyampakan tujuan yang harus dicapai siswa dalam pembelajaran. Keterampilan menjelaskan yang dilakukan guru sudah baik. Siswa di tunjukkan dengan media pembelajaran dan menanyakan tentang media tersebut serta menghubungkannya dengan materi pelajaran. Peneliti juga menjelaskan petunjuk cara menggunakan media pembelajaran dengan bahasa yang mudah dipahami.

Memasuki kegiatan inti, pengamatan keterampilan mengajar guru dilakukan sesuai dengan sintak model pembelajaran Jigsaw. Keterampilan yang diamati pada tahap pembentukan kelompok asal. Secara umum keterampilan peneliti dalam membentuk kelompok asal pada tahap pembentukan kelompok asal sudah baik. Dalam pembentukan kelompok asal sesuai dengan tingkat kecerdasan siswa yang berbeda-beda, hal ini dapat diketahui dari hasil prasiklus siswa. Pada saat siswa telah menempati kelompoknya masing-masing, peneliti sudah memberitahukan nama anggota kelompoknya, peneliti meminta siswa utuk mengingat nama kelompok dan nama anggota kelompoknya. Walaupun pada pertemuan awal banyak siswa yang lupa nama kelompoknya dan nama anggota kelompoknya pada saat siswa kembali ke kelompok asal. Namun di pertemuan berikutnya meminta siswa mencatan nama kelompok dan nama anggota kelompoknya.

Keterampilan pada tahap pembagian materi per subbab kepada anggota kelompok asal dilakukan dengan membagikan undian berupa lipatan kertas yang di dalamnya tertulis subbab materi. Keterampilan ini juga dilakukan dengan baik oeh peneliti karena selalu mengingatkan siswa untuk mengingat siswa subbab materi yang didapatkan masing-masing siswa. Hal tersebut sesuai dengan Fatkhurrohman (2015: 63) yang menjelaskan bahwa model pembelajaran Jigsaw merupakan model pembelajaran kooperatif dengan siswa belajar dalam kelompok kecil yang terdiri dari 4-6 orang secara heterogen dan bekerjasama saling ketergantungan yang positif dan bertanggung jawan atas ketuntasan bagian materi pelajaran yang harus dipelajari dan menyampaikan materi tersebut kepada anggota kelmpok lainnya.

Pengamatan keterampilan dalam pembentukan kelompok ahli dilakukan pada tahap-3 model pembelajaran Jigsaw semakin membaik. Pada tahap ini, peneliti meminta sesia untuk mendapat subbab bagian materi yangbsama berkumpul menjadi satu kelompok baru yang disebut kelompok ahli. Hal tersebut sesuai dengan Fatkhurrohman (2015: 63) yang menjelaskan bahwa kelompok ahli adalah kelompok siswa yang terdiri dari anggota 
Titin Safitri, Sucipto dan Henry Suryo Bintoro

Anargya: Jurnal Pendidikan Matematika, Vol. 1 No.2, Oktober 2018

kelompok asal yang berbeda yang ditugaskan untuk memperlajari dan mendalami topik tertentu dan menyelesaikan tugas-tugas yang berhubungan dengan topiknya untuk kemudian di jelaskan kepada anggota kelompok ahli.

Keterampilan membimbing siswa dalan diskusi kelompok yang dilakukan pada tahap diskusi kelompok ahli juga mengalami peningkatan pada setiap pertemuan. Ketika kelompok ahli melakukan diskusi, peneliti juga telah membimbing pada setiap kelompok, selain itu peneliti juga telah melakukan bimbingan dan memonitor siswa dalam melakukan diskusi kelompok. Peneliti juga memberikan wakktu yang cukup kepada siswa dalam melakukan diskusi dan mengerjakan lembar kerja siswa kelompok ahli. Setiap siswa dalam kelompok ahli harus saling membantu dalam mempelajari subbab materi yang didapat. Hal tersebut sesuai dengan pendapat Fatkhurrohman (2015: 63) yang menjelaskan bahwa kelompok asal adalah kelompok induk siswa yang beranggotakan siswa dengan kemampuan, asal, latar belakang keluarga yang beragam, kelompok asal merupakan gabungan dari beberapa ahli.

$$
\text { Pengamatan }
$$

keterampilan

mengembalikan kelompok ahli ke kelompok asal pada tahap kembali ke kelompok asal juga semakin meningkat, karena peneliti telas memberikan arahan kepada siswa untuk kembali ke kelompok asal mereka dan peneliti juga mebimbing siswa kembali ke kelompok asal. Setelah siswa kembali ke kelompok asal, peneliti membrikan kesempatan pada setiap siswa untuk memaparkan atau menceritakan subbab bagian materi di dapat dari kelompok ahli ke anggota kelompok asal. Setelah diskusi kelompok asal selesai, peneliti memberikan kesempatan yang sama pada setiap kelompok asal untuk mempersentasikan hasil diskusinya, peneliti juga membimbinga siswa yang tidak presentasi agar memperhatikan kelompok ynag presentasi.

Pengamatan keterampilan dalam mengelola kelas juga dilakukan dalam tahap 5 model pembelajaran Jigsaw. Kekuarangan peneliti pada siklus I terlihat pada keterampilan mengelola kelas, baik dalam pengelolaan siswa dalam kegiatan pembelajaran maupun pada pengelolaan alokasi waktu. Karena pembelajaran yang dilakukan pada siklus I dan melebihi alokasi waktu yang ditentukan. Hal ini dikarenakan siswa masih kesulitan dalam mengerjakan LKS dengan menggunakan permainan ular tangga tida dimensi (Ultra 3D) sehingga mereka membutuhkan waktu lebih dalam menyelesaikan LKS. Kekurangan tersebut juga dirasakan pada siklus II karena memang siswa lebih dalam menggunakan media pembelajaran untuk menemukan dan memahami konsep sifat-sifat bangun datar.

Keterampilan guru dalam memberikan kuis, pada tahap kuis jjuga sudah baik. Peneliti telah membagikan soal evaluasi kepada seluruh siswa. Peneliti juga memberikan petunjuk cara mengerjakan dan batas waktu yang diberikan dalam mengerjakan soal tersebut.

Keterampilan menutup pelajaran pada kegiatan penutup pada setiap pertemuan dilakukan peneliti baik, peneliti melibatkan siswa dalam memberikan refleksi, membuat kesimpulan, dan memberikan tindak lanjut diakhir pelajaran dan mengakhiri pelajaran dengan mengucapkan salam. Pembahasan mengenai peningkatan pemahaman matematis, aktivitas belajar sisw, dan keterampilan mengajar guru yang telah diuaraikan dapat disimpulkan bahwa penelitian tinakan kelas yang dilakukan sudah selesai dalam 2 siklus pembelajaran.

Hasil penelitian tindakan kelas yang dilakukan peneliti di perkuat dengan hasil penelitian terdahulu yang dilakukan oleh peneliti lain yakni penelitian yang telah dilakukan Nasruddin (2017) yang berjudul "Meningkatkan Hasil Belajar Matematika Melalui Model Pembelajaran Kooperatif Tipe Jigsaw pada Siswa SMP". Hasil penelitian tersebut menunjukkan bahwa pembelajran kooperatif tipe Jigsaw dapat meningkatkan hasil belajar siswa.

\section{SIMPULAN}

Hasil penelitian tindakan kelas yang telah dilakukan dapat disimpulkaan bahwa penerapan model jigsaw untuk peningkatan pemahaman matematis siswa dengan menggunakan permainan ular tangga tiga dimensi (ULTRA 3D) dapat meningkatkan pemahaman matematis, aktivitas siswa dan keterampilan mengajar guru. Hal ini dapat dilihat dari pencapaian indikator keberhasilan dalam penelitian sebagai berikut. (1) Meningkatnya hasil belajar pemahaman matematis siswa kelas III SDN 3 ngeling dengan penerapan model pembelajaran jigsaw dengan permainan ular tangga tiga dimensi (ULTRA 3D) pada sifat-sifat bangun datar dapat dianalisis sebagai berikut: nilai rata-rata siswa untuk nilai awal adalah 49,64, siklus I 68,11, siklus II 80,43. Sedangkan untuk ketuntasan klasikal di dapatkan data untuk konsisi awal adalah $64,29 \%$, siklus I $71,43 \%$, siklus II $82,14 \%$. Jadi, pada siklus II terdapat peningkatan sebesar $17,85 \%$ dari kondisi awal dan $10,71 \%$ dari siklus I. (2) Aktivitas belajar siswa dengan menggunakan model pembelajaran jigsaw dengan permainan 
ular tangga tiga dimensi (ULTRA 3D) pada sifatsifat bangun datar pada kelas III SDN 3 Ngeling meningkat yang semula pada siklus I memperoleh skor rata-rata 2,10 dengan kualifikasi "cukup baik" dan pada siklus II meningkat menjadi 2,53 dengan kualifikasi "baik". (3) Keterampilan mengajar guru dengan menggunakan model pembelajaran jigsaw dengan permainan ular tangga tiga dimensi (ULTRA 3D) pada sifat-sifat bangun datar pada kelas III SDN 3 Ngeling meningkat yang semula pada siklus I memperoleh skor rata-rata sebesar 3,07 dengan kualifikasi "baik" dan pada siklus II meningkat menjadi 3,35 dengan kualifikasi "sangat baik".

\section{UCAPAN TERIMAKASIH}

Penulis ucapkan terimakasih kepada Sucipto, M.Pd.Kons dan Henry Suryo Bintoro, M.Pd. yang telah memberikan arahan, bantuan dan pemikiran dalam penyusunan artikel. Selain itu penulis juga mengucapkan terimakasih kepada segenap tim Pengelola Jurnal Anargya yang telah memberikan kesempatan kepada penulis untuk mempublikasikan karya ilmiahnya.

\section{DAFTAR PUSTAKA}

Ani, A. Maulana, M. Sunaengsih, Cucun. 2017. Pengaruh Pendekatan Kontekstual Berbasis Kecerdasan Visual-Spasial terhadap Kemampuan Pemahaman Matematis Siswa Sekolah Dasar. Jurnal Pena Ilmiah. Vol. 2. No. 1. Hal 971-980.

Arsyad, Azhar. 2017. Media Pembelajaran. Jakarta: Rajawali.

Djamarah, syaiful Bahri. 2011. Psikologi Belajar. Jakarta. Rineka Cipta.

Fahrudhin, A.G., Zuliana. E., Bintoro, H.S. 2018. Peningkatan Pemahaman Konsep Matematika Melalui Realistic Mathematic Education Berbantu Alat Peraga Bongpas. Jurnal Ilmiah Pendidikan Matematika: ANARGYA. Vol. 1, No. 1. Hal 1-71.

Fathurrohman, Muhammad. 2015. Model-model Pembelajaran Inovatif. Jogjakarta: Arruzz Media.

Fauziyah, Priliyani. Maulana, M. Jayadinata, Asep Kurnia. 2017. Pengaruh Penggunaan Media "Segar" dan Permainan "Basis" pada Pendekatan Konttekastual untuk meningkatkan Kemampuan Pemahaman Matematis Siswa. Jurnal Pena Ilmiah. Vol. 2. No. 1. Hal 911-920.
Hamalik, Oemar. 2009. Proses Belajar Mengajar. Jakarta. PT Bumi Aksara.

Lestari, KA. Yudhanegara, MR. 2015. Penelitian Pendidikan (Panduan Praktis Menyusun Skripsi, Tesis, dan Karya Ilmiah dengan Pendekatan Kuantitatif, Kualitatif, dan Kombinasi Disertai dengan Model Pembelajaran dan Kemampuan Matematis). Bandung: PT Refika Aditama.

Nasruddin. Abidin, Zainal.2017. Meningkatkan Hasil Belajar Matematika Melalui Model Pembelajaran Kooperatif Tipe Jigsaw pada Siswa SMP. Journal of Educational Science and Technology. Vol. 3, No. 2. Hal $113-121$.

Puri, DAA. Lestari, Lies. Atmojo, IRW. 2017. Penerapan Pendekatan Realistic Mathematics Education (RME) Untuk Meningkatkan Pemahaman Konsep Sifat-Sifat Bangun Ru- Ang Pada Siswa Sekolah Dasar. Didaktika Dwija Indria. Vol. 5, No. 8. Hal 1- 8.

Soegiato, dkk. 2011. Pendidikan Pancasila. Semarang: Pusat Pengembangan MKU-MKDK UNNES.

Sugiyono. 2010. Metode Penelitian Pendidikan (Pendekatan Kuantitatif, Kualitatif, dan $R \& D)$. Bandung: Alfabeta.

Suprijono, Agus. 2013. Cooperative Learning Teori dan Aplikasi PAIKEM. Yogyakarta: Pustaka Pelajar.

Widayanti, Lilis. Hakim, Lukman. 2017. Pembelajaran Kooperatife Tipe Jigsaw sebagai Upaya Pendidikan Karakter pada Mata Kuliah Operation Research (Cooperative Learning Of Jigsaw Type As Efforts of A Character Education On Operation Research Lecture). Jurnal Matematika dan Pendidikan Matematika. Vol. 2. No. 1. Hal 78-89. 
